\title{
Ciężar wyboru, złożoność świata i jej redukcja. Gra w Go/Weiqi jako praktykowanie „metafizyki empirycznej”
}

\author{
Andrzej W. Nowak \\ Instytut Filozofii \\ Uniwersytet im. Adama Mickiewicza, Poznań \\ awnowak@amu.edu.pl
}

Przyjęto: grudzień 2017; zaakceptowano: grudzień 2017.

\begin{abstract}
Abstrakt
Celem podstawowym tekstu jest pokazanie, w jaki sposób gra w Go może posłużyć za modelowe przedstawienie ontologiczno-metafizycznego aspektu teorii aktora-sieci (ANT). Dodatkowym celem jest pokazanie i uwypuklenie kluczowego dla tej teorii aspektu onto-metodologicznej praxis.
\end{abstract}

Słowa kluczowe: gry; Go/Weiqi; metafizyka empiryczna; wyobraźnia ontologiczna; teoria aktora-sieci (ANT); studia nad nauką i techniką (STS)

\section{Wstęp}

Celem podstawowym tekstu jest pokazanie, w jaki sposób gra w Go może posłużyć za modelowe przedstawienie ontologiczno-metafizycznego aspektu teorii aktora-sieci (ANT). Dodatkowym celem jest pokazanie i uwypuklenie kluczowego dla tej teorii aspektu onto-metodologicznej praxis (Kuszyk-Bytniewska, 2015; Skórzyńska, 2017). Teoria aktora-sieci (ANT) jest sztandarową reprezentantką ogólniejszej tendencji w naukach społecznych i humanistyce, określanej jako zwrot ontologiczny (Heur van, Leydesdorff, Wyatt, 2013). Zapoznanie się z nią jest utrudnione przez specyficzny język tej teorii i konieczność znajomości tradycji związanej z antropologią laboratorium oraz studiów nad nauką i techniką (STS). Przywołanie STS i postaci Bruno Latoura często blokuje recepcję tego ujęcia na polu czysto filozoficznym, ze względu na jej

\footnotetext{
${ }^{1}$ Artykuł stanowi zmienioną i rozbudowaną wersję podrozdziału 3.2.4. Złożoność prostoty - dygresja o Go książki Wyobraźnia ontologiczna (Nowak, 2016, s. 268-283).
} 
uwikłanie w tak zwane wojny o naukę (Science Wars) (Kazibut, 2013; Tuchańska, 2006). Reprezentanci ANT (M. Callon, J. Law, B Latour, A. Mol) opatrzeni zostają etykietami: konstruktywizm, postmodernizm, nieklasyczna socjologia wiedzy, co powoduje, że pomimo podejmowanych coraz szerzej prób, recepcja filozoficznego i ontologicznego potencjału ich koncepcji na polu „czystej” filozofii jest utrudniona (Bińczyk, Derra, Grygieńć, 2015). Recepcji nie ułatwia także aktywność badaczy związanych z tak zwanym realizmem spekulacyjnym, szczególnie dotyczy to Grahama Harmanna (Harman, 2016). Wprowadzają oni co prawda ANT na „salony” filozofii, ale równocześnie z bardzo specyficzną i kontrowersyjną, moim zdaniem, interpretacją ANT, to znaczy pozostają oni na spekulacyjno-metafizycznym poziomie analizy. Osiągnięcia Latoura i innych przedstawicieli teorii aktora-sieci polegają nie na spekulacjach, ale na umiejętności przechodzenia pomiędzy wrażliwością na etnograficznie uchwytywany konkret a odwagą filozoficzną, która pozwala na filozoficzne (ontologiczne) wnioski. W takim ujęciu uwypuklająca aspekt praxis praca filozoficzna (oparta na dyspozycji badawczej zwanej wyobraźnią ontologiczną) pozwala (re)konstruować „krajobrazy metafizyczne” dzięki danym zebranym od „aktorów”, a nie tylko w ramach spekulacji odbywającej się w umyśle badacza (Nowak, 2013, 2016, s. 254-265).

Użycie odwołania do gry Go/Weiqi pozwala pokazać najważniejsze cechy ontologiczne i metafizyczne ANT oraz ukazać ważne dla tego ujęcia równoczesne współkonstytuowanie się praktyk metodologicznych wraz ze stabilizacją świata (ontologii) (Law, 2004). Uważam, że można prawomocnie zastosować odniesienie do gry Go/Weiqi z kilku powodów: po pierwsze odniesienie to pojawia się $\mathrm{w}$ kluczowych momentach $\mathrm{w}$ pracach samego Bruno Latoura (Latour, 2005; Latour, Woolgar, 1986, s. 247-252) oraz wcześniej u Deleuze’a i Guattariego (Deleuze, Guattari, 1988; Deleuze, Guattari, 2015). Po drugie przeniesienie ciężaru z odtwarzania tekstów autorów z zakresu ANT na pokazanie „pracy” tej teorii, ilustrowane odniesieniem do gry pozwala uchwycić wspomniany powyżej jej aspekt praxis. Po trzecie, skupienie na opowieści o grze i jej odtwarzaniu zrywa z teoriocentrycznym sposobem narracji, czyli tłumaczeniem ujęć filozoficznych wyprodukowanych jako teorie poprzez inne ujęcia teoretyczne. Jest to o tyle istotne, gdyż ANT jest teoriopraktyką, sposobem „wykonywania” bardziej niż klasyczną teorią. Dlatego w przypadku ANT kluczowe jest praktykowanie badania, a nie mówienie o nim. Filozof, który „gra w ANT" uczy się pewnej teoriopraktyki, której rezultat ujawnia się dopiero po „zagraniu w grę”. Używając innego, bardziej specjalistycznego języka, chcę pokazać w tekście, w jaki sposób można rozumieć ANT jako ontometodologię (Law, 2004) i ontografię (Lynch, 2013) - badanie metodologiczno-ontologiczne, które konstytuuje się wraz z badanym przezeń obiektem (Law, 2004). 


\section{Układ tekstu, uwagi techniczne i terminologiczne}

Układ tekstu: po wstępie w kolejnej części tekstu omówię specyfikę nieredukcyjnej metody filozofowania (metodo-ontologii), jaką jest teoria aktora-sieci. Następnie przedstawię szkicowo, w jaki sposób gra w Go/Weiqi była dotychczas używana jako model. W kolejnym kroku poprzez porównanie z grą w szachy wskażę na zasadniczo odmienny od ontoteologicznej tradycji europejskiej program ontologiczny ucieleśniany i artykułowany poprzez reguły oraz praktykę gry w Go. Omówię go bliżej w kolejnym fragmencie tekstu. W kolejnej zatytułowanej „Grając w zmienianie świata”, pokażę, w jaki sposób można równolegle opisać grę w Go oraz metodo-ontologię ANT jako wyraz podobnego programu filozoficznego. W części końcowej, zatytułowanej „Gra i ontologia wyboru” pokrótce zarysuję aksjologiczne konsekwencje tego programu.

Go/Weiqi - w większości przypadków będę stosował taki podwójny zapis, aby podkreślić chiński rodowód tej gry, znanej często z powodu jej znaczenia w kulturze Japonii. Istnieją jeszcze inne nazwy tej gry: igo (jap.) i baduk w Korei.

ANT - w tekście będę się posługiwał powszechnie przyjętym skrótem ANT na określenie teorii aktora-sieci (Actor-Network Theory).

STS - w tekście będę posługiwał tym skrótem na określenie studiów nad nauką i techniką (Science \& Technology Studies).

Wyobraźnia ontologiczna - to ufilozoficznienie Millsowskiej wyobraźni socjologicznej i dostosowanie jej do posthumanistycznej ontologii. Być obdarzonym wyobraźnią ontologiczną, to być zdolnym do analizy ontologicznej, która pozwala na rozpoznanie i potencjalnie przekształcenie sieci aktorów, układów bytów, które stabilizują naszą rzeczywistość, doświadczaną przez jednostki w ramach ich światów życia (Nowak, 2016).

„Metafizyka empiryczna” - w tekście posługuję się tym sformułowaniem, odwołując się do tradycji tak zwanego zwrotu ontologicznego (Heur van i in., 2013). Pomimo relatywnej „młodości” samego pola badawczego, jakim jest STS (30-40 lat), sama idea metafizyki czy ontologii empirycznej ujmowanej analogicznie sięga Whiteheada i Nietzschego (Law, Lien, 2013, s. 363). W tradycji STS używa się zwykle określenia „ontologia empiryczna” (Law, Lien, 2013; Woolgar, Pawluch, 1985), często $\mathrm{w}$ odwołaniu do samego Latoura używane jest też określenie „nowy empiryzm” (Krarup, Blok, 2011) oraz „empiryczna filozofia” (Latour, 2008). W tekście zdecydowałem się używać konsekwentnie terminu „metafizyka empiryczna”, choć przyznaję, że uzasadnione jest używanie wymiennie terminu „ontologia empiryczna”. Decyzję podjąłem przede wszystkim w oparciu o fakt, że odwołuję się głównie do najbardziej filozoficznego dzieła Bruno Latoura Irreductions (Nieredukcje) (Latour, 1988), a nie do bardziej empirycznych prac z zakresu teorii aktora-sieci, rezerwując termin „ontologia” do 
konkretnych empirycznych aplikacji tej metody filozofowania. Czym jest „metafizyka empiryczna” w interesującej mnie tradycji i przyjmowana także przeze mnie w niniejszym tekście, dobrze oddaje poniższy cytat:

W ujęciu Latoura abstrahowanie od kwestii metafizycznych oznacza przyjęcie błędnej wizji modernistów na temat ich własnego świata, jaki i konsekwencji tego - katastrofalnych praktyk eksploatacji planety. Pozytywną nadzieję upatruje on w studiach nad tym, co jest tu i teraz, oraz nad tym, jak się to przejawia (,what there is and what it is like"), czyli tym, co empiryczne, ale nie w naiwnym sensie, lecz ujmowane jako kolektywne, pragmatyczne i konkretne renegocjacje tego, co stanowi podstawowe warunki naszej egzystencji. Taki Latourowski aparat metafizyczny (metaphysical apparatus) ma na celu dostarczenie nam podręcznej ontologicznej skrzynki z narzędziami (ontological toolkit), której będziemy mogli użyć za każdym razem, gdy rozpoczynamy nasze badania, zarówno te empiryczne, jak i filozoficzne, dzięki czemu będziemy mogli każdorazowo podnosić kwestie tego, co jest, a co nie jest istotne. (Hämäläinen, Lehtonen, 2016, s. 14)

\section{Nieredukcyjna metodo-ontologia teorii aktora-sieci}

Rozpocznę od mocnej tezy - teoria aktora-sieci nie została dostatecznie wprowadzona w obręb debat filozoficznych. Wydawać się to może paradoksalne, zważywszy, jak szeroko i obficie napotkać możemy odniesienia do niej, szczególnie do postaci Bruno Latoura. Uważam jednak, że tym, co przykuwa uwagę, jest kilka wyrywkowo wyjętych z tej tradycji i ubarwiających artykuły humanistyczne „modnych słów” takich jak: ludzie vs. czynniki pozaludzkie (humans vs. non-humans), kłącze, sieć, zwrot ku rzeczom, sprawczość rzeczy etc. W poniższym tekście wychodzę z założenia, które poczyniłem też w swej książce (Nowak, 2016), że zasadniczy rdzeń filozoficzny ANT, przedstawiony przez Latoura w pracy Irreductions (Nieredukcje), jest relatywnie mało znany (Latour, 1988). W tym pisanym $\mathrm{w}$ punktach, podobnym $\mathrm{w}$ strukturze do Traktatu logiczno-filozoficznego Wittgensteina, tekście Latour przedstawia swój program ontologiczno-metafizyczny i wyjątkowo czyni to w sposób bezpośredni. To dość rzadkie w tamtym okresie jego twórczości, gdyż zwykle Latour-filozof skrywał się w cieniu Latoura-antropologa nauki. Nieredukcje także nie stanowią samodzielnej publikacji, ale są one drugą częścią książki Pasteryzacja Francji (pod takim tytułem ukazał się jej szeroko znany przekład angielski, francuski oryginał nosił tytuł Drobnoustroje: wojna i pokój) $)^{2}$. Program filozoficzny Latoura pozostał tłem prac z pogranicza etnografii laboratorium i STS, aż do czasu wydania książki An inquiry into modes of existence (Latour, 2013), która jest próbą podsumowania i połączenia obu wątków jego twórczości - filozoficznego i „empirycznego”. W niniejszym tekście skupię się na traktacie Nieredukcje ze względu na jego bardziej analityczny charakter. Latour-filozof

\footnotetext{
${ }^{2} \mathrm{~W}$ oryginale odpowiednio The Pasteurisation of France i Les Microbes. Guerre et paix, suivi de Irréductions.
} 
powoli zyskuje popularność i w tym sensie mój tekst wpisuje się w tę rosnącą tendencję. Szczególnie w tym kontekście warto zapoznać się z portretem biograficzno-intelektualnym Latoura nakreślonym przez Henninga Schmidgena (Schmidgen, 2015).

Wróćmy jednak do omawiania samego traktatu. Jest dla mnie ważne, że jak określiła to Knorr Cetina, Latour w Nieredukcjach formułuje podobną nietzscheańskiej teorię, wedle której całość rzeczywistości jest przeniknięta politycznością i walką (Knorr-Cetina, 1985, s. 581), co widoczne jest lepiej w nawiązującym do Tołstoja oryginalnym francuskim tytule jego książki. Ów „,wojenny” rdzeń nie stanowi „nakładki” społeczno-politycznej na „ontologiczne” podglebie, ale jest ściśle powiązany z propozycją ontologiczno-metafizyczną Latoura. Nie wydziela on osobnych rodzajów bytów i sfer rzeczywistości, lecz w Nieredukcjach stara się filozoficznie ująć mistyczne doświadczenie, które jak sam wyznaje było dla niego rodzajem epifanii (Latour, 1988, s. 163; Nowak, 2016, s. 233-244). Latour opisuje, jak będąc młodym nauczycielem filozofii, wracając $z$ pracy musiał zatrzymać auto, gdyż doświadczył czegoś przytłaczającego - rzeczywistość ujawniła mu się jako całkowicie niezredukowana, żadna $\mathrm{z}$ doświadczanych rzeczy nie była wpisana $\mathrm{w}$ ciągi przyczynowo-skutkowe, relacje zależności, wynikania zostały zawieszone. Jak sam stwierdza:

Nic nie może być zredukowane do niczego (czegoś) innego, nic nie może być wydedukowane z czegoś innego, wszystko może sprzymierzyć się z czymś innym”. To było jak egzorcyzm, który zwalczył demony jednego po drugim. Było wietrzne niebo, bardzo błękitne. [...] Niebo było na wyciągnięcie ręki, samoistnie ustanowione, samo definiowało swe miejsce, swe cele, ani znane, ani nie-znane. Ono i ja, ich i nas, wzajemnie się definiowaliśmy. I wtedy po raz pierwszy w moim życiu widziałem rzeczy niezredukowane i wolne. (Latour, 1988, s. 163)

Doświadczenie opisane przez Latoura może być porównane do postulatów Heideggera, gdy proponował strategię Gelassenheit, czyli „pozwolenie rzeczom być" (Heidegger, 2001), albo podobne do zanurzenia w bytowości na wzór doświadczenia religijnego, opisywanego przez Wiliama Jamesa (James, 1958, s. 67-68). Doświadczenie, epifania to początek pracy filozoficznej Latoura, w swym traktacie równocześnie stara się on nie tylko zrekonstruować świat, złożyć go na nowo, ale także pokazuje, w jaki sposób możliwe jest równoczesne istnienie zarówno owego doświadczonego w epifanii świata „niezredukowanego", jak i tego doświadczanego na co dzień w jego już zawsze zredukowanej postaci. W Nieredukcjach proponuje on początkową wersję ontometody, procedury ontologicznej, którą następnie rozwiną inni badacze $z$ kręgu ANT, między innymi John Law (Law, 2004). Polega ona na proceduralnym, metodologicznym zawieszeniu aktualnych relacji przyczynowoskutkowych, stanów rzeczywistości, a następnie przy pomocy drobiazgowej pracy empirycznej (opartej o „gęsty opis”, radykalną metodę etnograficzną) prześledzeniu, w jaki sposób doszło do redukcji świata do takiej postaci, z jaką 
aktualnie obcujemy. Program Latoura, pomimo pozornej nowości, jest ontologiczną wersją Husserlowskiej epoche. U wczesnego Husserla epoche oznaczało „wstrzymanie”, „zawieszenie” sądów sensotwórczych w obrębie pracy umysłu. W przypadku późnego Husserla i w ramach socjologii fenomenologicznej, będącej kontynuacją jego badań (Schutz, Berger, Luckmann), matrycą sensotwórczą wyznaczającą horyzont sensu nie był już dłużej wyłącznie solipsystycznie zamknięty umysł, ale świat życia - Lebenswelt. Epoche w tym wypadku oznaczało umiejętność „zawieszenia” aktualnych reguł kulturowych i społecznych, wyznaczających pole sensu oraz dokonanie analizy samej konstytucji tego pola (Abriszewski, 2016). Latour w Nieredukcjach proponuje zabieg analogiczny, zasadnicza różnica polega jednak na tym, że nie zatrzymuje się on na tradycyjnym podziale na świat podmiotu i świat przedmiotowy („rzeczy”), wyznaczonym przez neokantyzm. Socjologia fenomenologiczna, pomimo że uwzględniała rolę „rzeczy” w konstytuowaniu horyzontu sensu (Lebensweltu), zasadniczo była asymetryczna, ograniczała się do analizy świata ludzkiego, społecznego. Latour w swym radykalizmie wykracza poza ów postkantowski binaryzm i pokazuje, że także ów binaryzm to tylko jeden ze sposobów, w jaki „świat się zredukował”.

Pomimo barokowego języka Latour w Nieredukcjach proponuje bardzo skromny zestaw reguł podstawowych, które pozwalają zrekonstruować jego ujęcie rzeczywistości. Warto zauważyć, że skromność ta może być myląca, wyznacza ona bowiem jedynie bazowe założenia metodo-ontologiczne, które należy przyjąć przy badaniu tego, w jaki sposób świat „się redukuje”, to znaczy, w jaki sposób dochodzi do stabilizacji tej właśnie wersji rzeczywistości, która zaistniała. Doświadczając „epifanii” czy dokonując czysto spekulatywnej, filozoficznej operacji zontologizowanej epoche jesteśmy świadomi, że owa redukcja jest tylko jedną z możliwych form rzeczywistości - tą, która zwyciężyła, ukonstytuowała się. To wpisuje się $\mathrm{w}$ nietzscheański, zapożyczony od Deleuze'a, charakter filozofowania Latoura (Deleuze, 1993; Knorr-Cetina, 1985, 1985; Latour, 1988, s. 251).

Przyjrzyjmy się zatem podstawowym ideom konstrukcyjnym jego ontometody:

1. Każdy byt, ludzki i pozaludzki, który manifestuje się w swej egzystencji, nie może być zredukowany ani wyprowadzony z innego bytu.

2. Wszystko jest relacyjne, aktorzy/aktanci wchodzą bowiem nieustannie w sojusze i to konfiguracje tychże tworzą rzeczywistość.

3. Aktorzy w badaniu a priori ujmowani są jako konkretne, nieredukowalne byty, założenie to wynika z metodologicznego postulatu radykalnej symetrii. Oznacza on, że nie przesądzamy, nie narzucamy żadnych przesądzeń badanej rzeczywistości, dotyczących własności bytów, o ile nie wyprowadzimy ich z analizy onto-metodologicznej. 
4. Nie dotyczy to jednak już istniejących całości, na które składają się zbiorowości/kolektywy. Są one równocześnie traktowane jako nieredukcyjne, gdy myślimy o częściach składowych, i historyczne, kiedy myślimy o nich jako już uformowanych zbiorowościach (asamblażach).

Dokonując przeformułowania, możemy to ująć następująco:

1. Świat składa się z aktorów/aktantów - są oni równoważni, definiowani przez swą sprawczość rozumianą jako zdolność do konstytuowania rzeczywistości.

2. Zasada nieredukcji (irredukcji) - żaden obiekt a priori, na podstawie jakiejś przedwstępnej zasady, nie jest redukowany do jakiegoś innego. Nie ma żadnej metafizycznej ramy odniesienia, która byłaby uprzywilejowana względem innych ram. Irredukcja jest postulatem, od którego zaczynamy badanie splotów danych zbiorowości, asamblaży. Mówiąc innym językiem, zakładamy świat jako niezredukowany na „wejściu”, ale nie na „wyjściu” danego procesu badania filozoficznego $w$ duchu teorii aktora-sieci. Zatem $z$ jednej strony żaden obiekt nie może zostać sprowadzony do innego (przez badacza-filozofa mocą apodyktycznej pracy rozumu), ale równocześnie doświadczenie codzienności to nic innego jak doświadczanie redukcji, jaka zaszła przy konstytucji tego właśnie stanu rzeczywistości.

3. Translacja - to sposób, w jaki zachodzi proces samoredukcji świata. Może być ona rozumiana jako radykalny zakaz hipostazowania. Czynniki sprawcze w ujęciu Latoura, Lawa czy Mol zawsze muszą być ukazane poprzez odwołanie do „indykatora” - wskaźnika. Jeżeli w badaniu nie możesz wykazać wskaźnika, na podstawie którego wnioskujesz o danym oddziaływaniu, to z konieczności jesteś skazany na ontologiczny agnostycyzm. Zadanie to jest o tyle utrudnione, że wraz z redukowaniem się świata jego przeszłe stany zostają ukryte, stają się przezroczyste, a praca (sprawczość) i relacje, które spowodowały jego aktualny stan stają się niewidoczne (Star, 1999, s. 381). Wyprzedzając tok narracji, można to świetnie zaobserwować, analizując planszę zakończonej gry w Go/Weiqi. Widzimy formacje kamieni (pionów), możemy rozstrzygnąć, kto zwyciężył, ale sama rozgrywka, jej historia jest przed nami w dużej mierze ukryta. Ukazanie niewidocznej pracy sprawczości w już ukonstytuowanych asemblażach jest moim zdaniem kluczowym aspektem ANT, ważniejszym od bardziej znanej dekonstrukcji dychotomii tego, co ludzkie, i tego, co pozaludzkie (non-humans). Wskazanie na aspekt translacji uwypukla kluczowy dla ANT aspekt analizy stabilizowania, podtrzymywania i destabilizowania porządku tożsamego $\mathrm{z}$ chwilowym, przemijającym, ale aktualnie obowiązującym stanem doświadczanej rzeczywistości. Teoria aktora-sieci pozwala zrekonstruować, rozsupłać złożone sieci aktorów (jako mediatorów), które pozwoliły zaistnieć naszemu światowi, ustabilizować go, ale co więcej, pozwala dostrzec niewidoczny wysiłek (pracę), który musiał zostać 
włożony, aby do tego ustabilizowania, utworzenia sieci doszło oraz ukazuje eksternalizowane koszty tego procesu (Abriszewski, 2008).

4. Aktorzy nie są słabi ani silni dzięki jakiejś wewnętrznej istocie, lecz zyskują oni siłę lub słabość dzięki relacjom i swym sojusznikom. Także w tym aspekcie ujawnia się nietzscheański charakter systemu filozoficznego Latoura (Knorr-Cetina, 1985). W jego ujęciu świat jest przepełniony negocjacjami, intrygami, kalkulacjami, aktami perswazji i przemocy, dzięki którym aktor czy też siła przyznają sobie władzę lub powodują, że zostaje im ona nadana, by mówić lub działać w imieniu innego aktora bądź siły. Sojusze (alliances) to określenie sposobu bycia bytów rozumianych radykalnie relacyjnie, gdy porzucimy założenie o „głębszej” istocie; sojusze są jedynymi sposobami nabywania własności przez byty oraz budowania większych całości. Nie ma własności potencjalnych w mocnym sensie, to znaczy cech, które przetrwałyby pomimo relacji. Połączenie aktorów, tworzenie sieci powiązań to nabywanie realności i mocy. Istnienie jest pochodną ilości i jakości połączeń: „Teza 1.1.5. Cokolwiek opiera się próbom, jest rzeczywiste” (Latour, 1988, s. 158). Tutaj ujawnia się też niebezpieczeństwo Latourowskiej ontologii - jest ona metafizyczną wersją darwinizmu i koresponduje z jej wyrazem w myśli Nietzschego. Zakłada podobną definicję istnienia widoczną w tautologicznej zasadzie „przetrwania najlepiej dostosowanych" (survival of the fittest). Istnieje to, co jest najlepiej dostosowane do danego stanu świata, a wiemy o tym dlatego, że owo „coś” zaistniało, gdyby nie było dostosowane, to by nie istniało. Takie ujęcie ontologiczne powoduje wiele problemów z aksjologią (Nowak, 2015), równocześnie pokazując kolejny wymiar porównania pomiędzy ANT a wykorzystywaną jako symulacja wojenna, grą w Go/Weiqi (Boorman, 1969; Lai, 2004; Wasik, Cynarski, 2005).

\section{Go jako metafora i model}

Zasadniczą trudnością związaną z głównym zamysłem tekstu jest ryzyko, że będzie on obarczony ryzykiem błędu ignotum per ignotum, oto tłumaczyć będę relatywnie mało znany system filozoficzny, odnosząc się do równie mało znanej gry w Go/Weiqi. Ośmiela mnie jednak do podjęcia tej próby fakt, że ilustrowano teorię aktora-sieci odwołaniem do rzeczywistości pozateoretycznej, ciekawym przykładem jest użycie klocków LEGO do ilustrowania atomistycznej ontologii (Maddalena, 2014), oraz to, że używano gry w Go/Weiqi do ilustrowania koncepcji teoretycznych i filozoficznych, na przykład koncepcji stojących u podstaw działania Mao Tse-Tunga w czasie wojny partyzanckiej (Boorman, 1969) czy szerzej polityki Chińskiej Republiki Ludowej (Lai, 2004). Znaczenie kulturowe Go/Weiqi w Chinach i krajach sąsiednich jest znaczące 
(Moskowitz, 2013, s. 14-30) i obejmuje literaturę, filozofię, politykę oraz kształtuje role płciowe. Gra w Go/Weiqi ma także wymiar religijno-mistyczny zarówno w Chinach, jak i Japonii (Moskowitz, 2013, s. 34-42).

Dobrym wprowadzeniem dla polskiego czytelnika jest książka Janusza Kraszka Świat Go (Kraszek, 2008). Ze względu na wciąż relatywnie słabą obecność gry Go w polskim kontekście ${ }^{3}$, zrekonstruuję najpierw same zasady gry, a następnie pokażę przykłady stosowania gry w Go jako modelu dla różnych aspektów rzeczywistości.

Sprzęt do gry w Go/Weiqi składa się z 180 czarnych i 180 białych pionów, zwanych kamieniami. W odróżnieniu od figur szachowych, kamienie w grze Go są tak samo „cenne” i mają takie same własności. Właściwiej można by powiedzieć, że w takim samym stopniu nie mają one żadnych własności. Plansza (goban) do gry w Go składa się z 19 linii krzyżujących się w pionie i poziomie. Na planszy znajdują się wyróżnione miejsca zwane gwiazdami (hoshi). Są one ważne przy grze $\mathrm{z}$ handicapami, ale nie różnią się co do istoty od innych skrzyżowań.

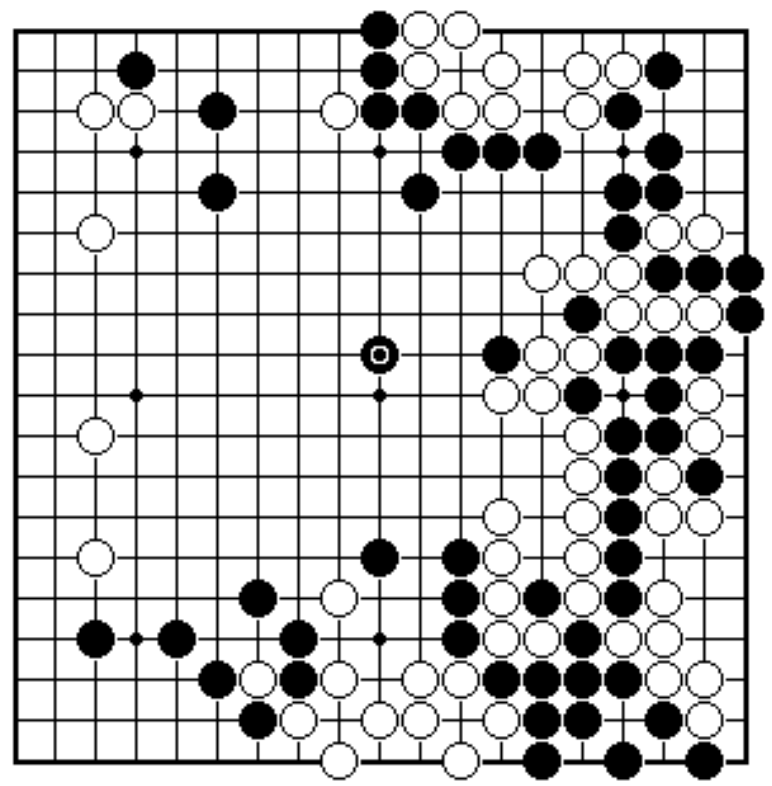

Rys. Przykładowy diagram przedstawiający grę w Go, w tym wypadku grę mistrza Go - Honinbo Shusaku. Za: https://pl.wikipedia.org/wiki/Go.

\footnotetext{
${ }^{3}$ Krótką historię Go w Polsce oraz spis książek i publikacji na ten temat można znaleźć na stronie polskiego stowarzyszenia goistów: http://biblioteka.go.art.pl/taxonomy/term/3.
} 
Celem gry jest zdobywanie terytorium przy możliwie najmniejszych stratach własnych. Gra jest przeznaczona dla dwóch graczy. Kamienie kładziemy naprzemiennie na skrzyżowaniach, przecięciach linii. Istnieje kilka bardzo prostych reguł, które opisują grę. Możemy kłaść jeden pion naraz na skrzyżowaniu. Piony łączą się w łańcuchy, jeżeli zajmują sąsiednie pola. Gdy kamienie sąsiadują z pustym skrzyżowaniem mają tak zwany oddech. Brak pustego skrzyżowania, oddechu powoduje, że pion „nie żyje” i zdejmujemy go z planszy. Celem gry jest stworzenie takich struktur z kamieni, które „przeżyją” i umożliwiają równocześnie zajęcie największej ilości planszy przy najmniejszych stratach własnych. W grze istnieje jeszcze kilka drobnych reguł dodatkowych, których nie trzeba na potrzeby tego tekstu omawiać.

Gdy przyjrzymy się grze w Go, początkowo wydaje się ona pozornie mniej skomplikowana i zajmująca niż szachy, gdy jednak zaczniemy w nią grać, okazuje się, że przerasta ona złożonością szachy wielokrotnie. Wiąże się to częściowo z wielkością planszy i ilością pionów, poziom złożoności jest znacznie wyższy niż w przypadku szachów. Jest on na tyle wysoki, że nie sposób ogarnąć i zaplanować całej gry, bazując jedynie na podejściu „obliczeniowym” oraz na analizowaniu jednego konkretnego problemu. Z racji otwartości, możliwości wielokierunkowego rozwoju gry, gracze nieustannie muszą przerzucać swoją uwagę z jednej części planszy na inną. Równocześnie podejmują decyzje, dotyczące zagrania taktycznego, czyli zbudowania lokalnych struktur, jak i holistycznie planują rozwój całej gry. Gra składa się z trzech, tradycyjnie wyszczególnionych faz: otwarcia (fuseki), fazy środkowej (chuban) i końcowej (yose). $\mathrm{W}$ tradycyjnych partiach postawienie pierwszych kilkunastu ruchów jest kluczowe, wyznacza ono bowiem sfery wpływów. Często czasowo zajmuje to dłużej niż pozostałe części gry. Jednakże to druga, środkowa faza gry jest najtrudniejsza. To właśnie w tej części gry najwięcej zależy od intuicji i zinternalizowanych umiejętności, w odróżnieniu od fazy początkowej i końcowej, które w większym stopniu można poddać kodyfikacji.

\section{Szachy i Go/Weiqi - granie a ucieleśnianie (różnych) ontologii}

Wierny przykazaniu „podążaj za aktorem” porównania Go oraz ANT dokonuję ośmielony znaleziskami, wskaźnikami odnalezionymi w samej twórczości Latoura. W Nieredukcjach przywołuje on powieść Meijin - mistrz go (Kawabata, 2004) w tezie, która brzmi:

1.1.11 Wszystko jest wciąż w grze. Jakkolwiek, ponieważ wielu graczy próbuje uczynić grę nieodwracalną i czynią wszystko, aby upewnić się, że nie wszystko jest tak samo możliwe, gra jest skończona. Hołd złożony Mistrzowi Go ${ }^{4}$. (Latour, 1988, s. 160)

\footnotetext{
4 "Everything is still at stake. However, since many players are trying to make the game irreversible and doing everything they can to ensure that everything is not equally possible, the game is over. Homage to the Masters of Go” (Kawabata, 1972).
} 
Fragment ów jest poprzedzony wskazaniem, że każde działanie aktorów pozostawia ślad, historię, działanie wytwarza asymetrię, ta pozostawia ślad, wpływa na to, jaki stan przybierze rzeczywistość, wyłoni się z walki, a przegrani i zwycięzcy złożą się na jej kształt. Odwołanie do Go w tak ważnym miejscu Latourowskiego traktatu filozoficznego nie jest jedynie ornamentem, ale stanowi także ważną wskazówkę interpretacyjną. Przykładam do niej dużą wagę dlatego, że uważam Latoura za autora, który podobnie do Heideggera ,jak lis zamazuje ogonem swoje ślady”. Latour konstruuje swe teksty tak, aby czytelnik odnosił wrażenie ich oryginalności i nowości, dlatego odniesienia do inspiracji intelektualnych są często ukryte. Przykładem odsłaniającym tę strategię jest tekst Wizualizacja i poznanie (Latour, 2012), w którym dość wyjątkowo Latour pokazał swe inspiracje intelektualne (szkoła z Toronto, teoria oralności/piśmienności). Co ciekawe tekst oryginalny ukazał się w 1986 roku i w późniejszych pracach Latoura odwołanie do wspomnianych tradycji jest znikome. Zakładając tę specyfikę autora, uważam, że rozproszone drobne uwagi dotyczące gry w Go mają dużo większe jakościowe znaczenie w rekonstrukcji systemu filozoficznego Latoura niż wskazywałaby na to ilość odwołań.

Będąc równocześnie czytelnikiem Latoura i Lawa oraz mając doświadczenie w grze w Go, dość wyraźnie uwidacznia się dla mnie, że „metafizyka empiryczna”, jaka jest założona, a następnie ucieleśniana i odgrywana w ramach tej gry, jest właśnie praktykowaniem podstawowych zasad filozoficznych zawartych w Nieredukcjach. Obcość i specyfika języka ANT polega między innymi na jej odmienności od „standardowej metafizyki euroamerykańskiej” (Law, 2004), której dobrym przykładem może być system arystotelesowski czy bardziej ogólnie systemy ontoteologiczne (Kostyszak, 2010). Z tego powodu wygodnie będzie zilustrować system Latoura poprzez splecenie go z metaforą gry w Go i zestawienie go z tak zwaną standardową metafizyką, ilustrowaną metaforą gry w szachy. Porównanie to jest często stosowane i stanowi wariant ogólniejszych porównań pomiędzy „umysłowością Wschodu i Zachodu” wraz z potencjalnym eurocentrycznym i politycznym obciążeniem takiego zabiegu (Moskowitz, 2013, s. 30-34).

„Szachy są głęboko metafizyczne. Różne figury mają różne moce, własności i zadaniem gracza jest, aby umieścić je w idealnych okolicznościach, w których mogą one się ujawnić. Wieża, przykładowo, może zdominować wiele pól na planszy, ale na początku jej moce są wstrzymane, uwięzione za murem pionów własnego koloru. Potęga figury może być zrozumiana jako potencjalność, możliwość, która jest dostępna, o ile jest nieograniczona (unhindered). Królowa zagraża większej ilości pól niż pionek, ale nawet on w odpowiedniej sytuacji może odegrać ważną rolę. Podczas gry większość tych możliwości nie zostaje zaktualizowana. Każdy ruch zamyka stare możliwości i tworzy nowe. Jeżeli ktoś chce zrozumieć metafizykę przyczynowości, szachy stanowią dobry punkt startu”. (Mumford, 2013) 
W powyższym cytacie widać wyraźnie ucieleśnienie metafizyki Arystotelesa w zasadach gry w szachy. Figury mają określone własności, formy. Formy te są potencjalne, czekają w uśpieniu, aktualizacja jest możliwa dzięki rozmaitym konfiguracjom, tworzą nowe dynamiczne (w sensie dynamis) układy. Pewne aspekty figur uwypuklają się, inne schodzą na dalszy plan. W niektórych sytuacjach ważne jest, że królowa ma zdolność poruszania się po całej planszy, w innych, że bije ona w każdym kierunku. W przypadku pionów raz jest ważne, że biją one na skos, a raz, że po dojściu na ostatnie pole można je zamienić na dowolną inną figurę (poza królem). Figury szachowe zatem mają jasno określony rdzeń, esencje, lecz podlegają one znacznej modyfikacji w zależności od relacji, w których uczestniczą. Relacje te jednak są jedynie aktualizacjami potencji, w tym sensie świat szachów, podobnie jak metafizyka Arystotelesa, pomimo swej dynamiczności, zmienności nie pozwala na zaistnienie momentu pustki, kreacji. Przejdźmy teraz do rekonstrukcji gry w szachy oraz w Go w Traktacie o nomadologii (Deleuze, Guattari, 1988). Pozwoli to z jednej strony uchwycić różnice pomiędzy obiema grami w kategoriach filozoficznych, z drugiej - pokazać powiązanie pomiędzy rizomatyką i teorią aktora-sieci a grą w Go:

Należałoby wziąć ograniczony przykład, porównać maszynę wojenną i aparat państwa, posługując się teorią gier. Weźmy szachy i Go z punktu widzenia ich elementów, stosunków pomiędzy elementami i obejmowanej przestrzeni. Szachy są grą państwa albo dworu, gra w nie cesarz Chin. Figury szachowe są kodowane, mają charakter wewnętrzny albo też wewnętrzne własności, z których wynikają ich ruchy, sytuacje starcia. Mają jakości - skoczek pozostaje skoczkiem, piechur piechurem, goniec gońcem. Każdy jest czymś w rodzaju wyposażonego w relatywną władzę przedmiotu wypowiedzi; i te relatywne władze łączą się w podmiocie wypowiedzenia, $\mathrm{w}$ samym szachiście albo w formie wewnętrzności gry. Piony go, przeciwnie, są ziarnkami, pastylkami, prostymi jednostkami arytmetycznymi i nie mają innej funkcji prócz funkcji anonimowej, zbiorowej albo trzecioosobowej. „On” się posuwa, może to być mężczyzna, kobieta, pchła, słoń. Piony go są elementami nie-subiektywnego urządzenia mechanicznego, elementami pozbawionymi własności wewnętrznych, posiadających zaś stosunki sytuacyjne. Toteż w obu przypadkach zachodzą odmienne stosunki. W swym otoczeniu wewnętrzności figury szachowe utrzymują pomiędzy sobą oraz figurami przeciwnika stosunki wzajemnie-jednoznaczne: których funkcje mają charakter strukturalny. Tymczasem pion go ma tylko otoczenie zewnętrzności albo zewnętrzne stosunki z mgławicami, konstelacjami, stosunki, zgodnie z którymi pełni funkcję insercji czy sytuacji takiej jak obsadzić, okrążyć, wysadzić. Jeden jedyny pion może unicestwić jednocześnie całą konstelację, podczas gdy figura szachowa nie może/może to uczynić tylko diachronicznie. (Deleuze, Guattari, 1988, s. 204) ${ }^{5}$

W powyższym cytacie zarysowuje się metafizyczny spór, który toczą ze sobą ontologie wykonywane przez obie gry. Świat Latoura, tak dobrze opisywany przez reguły i praktykę gry w Go, jest zupełnie inny niż ten przedstawiany w szachach, zamiast metafizyki formy i materii mamy do czynienia z kłączem.

${ }^{5}$ Zwrócenie uwagi na powyższy cytat zawdzięczam Krzysztofowi Abriszewskiemu. 
Widoczne jest to też w odmienności treningu strategicznego i taktycznego, jaki uzyskują gracze w szachy i Go (Boorman, 1969, s. 4-7). W klasycznej zachodniej myśli wojennej kluczowe było szybkie wygrywanie bitew, dążenie do bezpośredniej konfrontacji $\mathrm{z}$ użyciem przytłaczającej liczby jednostek wojskowych, mających przełamać opór przeciwnika. W tradycji chińskiej (i japońskiej) gra w Go/Weiqi przez wieki kształtowała wyobraźnię wojenną (strategiczną i taktyczną) zarówno generałów, jak i polityków (Moskowitz, 2013, s. 42-47), czego ślady możemy odnaleźć zarówno w Sztuce Wojny, jak i w dziełach Mao Zedonga. Jak zauważa Hong Feng, cytowany przez Moskowitz:

W starożytnych Chinach używano podręcznika do uczenia gry w Weiqi, który został zakazany przez rząd, ponieważ Weiqi jest jak wojna. Ludzie są sprytni [smart], więc jeżeli wiedzieliby, jak grać w tę grę, to poznaliby strategie, których mogliby użyć do walki z rządem. Z tego samego powodu odniesienie biblioteczne kataloguje książki o Weiqi obok Sztuki Wojny Sunzu. W niej jest zawarta podstawowa strategia wygrywania wojen bez bitew i walki. To najwyższa forma wojny. Bycie uległym i unikanie zabijania. Weiqi naucza podobnej strategii. (Moskowitz, 2013, s. 42)

Powyższe uwagi możemy odnaleźć $\mathrm{w}$ postępowaniu Mao podczas wojny chińskiej wyzwoleńczej. W pismach z tego okresu wprost powoływał się na inspirację Go/Weiqi (Boorman, 1969, s. 6), kluczowe było dla niego działanie niebezpośrednie, nastawione na przewlekanie konfliktu skupione na kształtowaniu relacji sieci niż na rozstrzyganiu pojedynczych bitew:

Jest to już drugi rodzaj przeciwokrążenia nieprzyjaciela przez nas. Tak więc te dwa rodzaje wzajemnego okrążania przypominają w ogólnym zarysie grę „weici” - bitwy i walki, jakie nieprzyjaciel prowadzi z nami i my z nim, przypominają „zjadanie bierek”, a punkty oporu nieprzyjaciela (na przykład miasto Taijuan) i nasze partyzanckie bazy oporu (na przykład rejon Wutaiszanu) przypominają „okienka” na szachownicy6. (Mao, 2012 (1938), s. 41)

Szachy wymagają rozstrzygnięcia napięć pomiędzy istniejącymi jakościami (figurami), podczas gdy gra w Go wymaga równoczesnego stwarzania struktur, które dzięki temu uzyskują „jakość” i rozgrywania napięć pomiędzy nimi. Gra w Go uczy myślenia jako zarządzania warunkami brzegowymi, które powodują, że stany rzeczy przyjmują daną postać, a nie tak ważnego w ontoteologii dociekania istoty rzeczy:

[...] w późnym okresie 1948 roku [...] Mao stwierdził, „Jeżeli te dwa punkty, Tangku (najważniejszy) oraz Hsinpao-an będą zdobyte, to będziemy mieli inicjatywę na całej planszy”. Chiński idiom użyty przez Mao na końcu tego zdania „ch’iian-chii chieh huo-le” w dosłownym tłumaczeniu oznacza „całość będzie żyć”

\footnotetext{
${ }^{6}$ Oczywiście wbrew potencjalnie mylącemu przekładowi, chodzi o goban - planszę do gry w Go, wspomniane „okienka” zaś to formacje pionów zdolne do „przeżycia”.
} 
(„the whole situation will be living”), wyrażenie dziwaczne dla zachodniego czytelnika, ale nawiązujące do idiomu z gry wei-ch’i. (Boorman, 1969, s. 7)

Przywołanie Mao, Deleuze’a i Guattariego pozwoliło pokazać przejścia pomiędzy modelami filozoficznymi, praktykami wojennymi oraz grą w Go/Weiqi. Warto dodać, że język metafor Mao Zedonga obecny jest u Latoura, Deleuze’a i Guattariego także we fragmentach niedotyczących bezpośrednio gry w Go/Weiqi. Szczególnie frapujące, zważywszy na książkę Tysiąc plateau, jest użycie przez Mao odniesień do masywów i wysepek jako punktów rozproszonego oporu (Mao, 2012 (1938), s. 44), niestety bliższa analiza tej relacji przekracza ramy niniejszego tekstu, choć pozostaje intrygujące, że Deleuze i Guattari w swej analizie wojny partyzanckiej („nomadycznej machiny wojennej”) wprost odwołują się do beduińskich taktyk opisanych przez Lawrence’a w Siedmiu filarach mądrości (Deleuze, Guattari, 2015, s. 513), a nie wspominają Mao (Thoburn, 2008, 2013).

W tym miejscu porzucę dalsze rozwijanie tych analogii i przejdę do ściślejszego pokazania paraleli pomiędzy grą w Go a teorią aktora-sieci. „Metafizyka empiryczna”, czyli propozycja ontologiczna, której ucieleśnienie stanowi Go, jest fascynująca. Z jednej strony mamy do czynienia z zespołem bardzo prostych reguł. Zarówno kamienie/piony, jak i przecięcia/skrzyżowania nie mają właściwości. Oznacza to, że dopiero podczas gry, w trakcie budowy formacji ujawniają się ich własności. Granie nie polega na powiązaniu „gotowych reguł” i wykryciu relacji pomiędzy nimi, ale jest dużo bardziej złożone. Równocześnie konstruujemy całości (formacje kamieni), rozpoznajemy ich własności (jako formacji, wynikające $\mathrm{z}$ własności danego asemblaża) oraz relacje pomiędzy asemblażami (formacjami), ponadto trzeba uwzględnić także środowisko gry, czyli planszę i jej własności przestrzenne. Nie są one traktowane po kartezjańsku jako abstrakcyjna przestrzeń, ale jako jakościowo znaczące miejsce (Tuan, 1987). Podobnie traktowane są własności formacji kamieni („pionów”), konstytuowane każdorazowo wraz z wyłaniającymi się strukturami, a nie przypisane „na stałe” do kamieni czy planszy. Pomimo że początkowo ilość reguł jest mniejsza niż w szachach, to w trakcie gry ilość konfiguracji, możliwości ewolucji danych struktur jest ogromna. Uczenie się gry w Go z jednej strony polega na ćwiczeniu zdolności, które możemy nazwać taktycznymi albo zdolnościami czytania wzorców. To umiejętność dostrzegania już po dwóch, trzech ruchach dynamiki rozwijającego się układu. Układy te są od setek lat kodyfikowane $\mathrm{w}$ literaturze przedmiotu, od najprostszych tak zwanej „drabinki” czy „żurawia” po bardziej złożone często tradycyjnie przypisywane mistrzom, którzy mieli je wynaleźć. Drugą umiejętnością ściśle powiązaną jest zdolność do „czytania” całej planszy, całościowego pojmowania sensu, kierunku rozwoju gry. To zdolność do pewnego holistycznego i strategicznie kluczowego ujmowania całej złożoności gry w pewnym, fenomenologicznym oglądzie. Co ważne w świecie graczy w Go, umiejętność gry nie zamyka się jedynie w techne, sprawności grania, obejmuje także pewien całościowy zestaw 
reguł postępowania w czasie partii. Kraszek wymienia między innymi takie reguły: grający nie powinni opierać głowy na łokciu, trzymać piona w trakcie myślenia etc., czyli nie wykraczać przeciwko temu, co nazywane jest „duchem go” (Kraszek, 2008, s. 32). Reguły te stanowią równie ważny element podczas nauczania gry w Go/Weiqi jak czysto techniczne opanowanie umiejętności gry. Moskovitz podkreśla ponadto rodzące się dziś napięcie pomiędzy klasycznym, konfucjańskim ideałem, ucieleśnianym i praktykowanym podczas gry w Go/Weiqi, a współczesnymi wymogami, wynikającymi z korporacyjnych struktur zawodowych klubów sportowych (Moskowitz, 2013, s. 77-80).

\section{Kładąc kamienie - gra w Go a wykonywanie i ucieleśnianie ontologii}

Przyjrzyjmy się zatem bliżej samej „ontologii gry”: podobnie jak w założeniach ANT, istnieją aktanci („kamienie”), to, co sprawcze, ich wzajemne relacje i sojusze wyznaczają sfery tego co możliwe. Świat jest polem gry sił, te z kolei są efektem konfiguracji i sojuszy aktorów. Ontologia gry w Go/Weiqi jest równie „płaska” jak ta przyjmowana w ramach teorii aktora-sieci. ANT tak jak gra w Go/Weiqi (i jej wewnętrzna ontologia) jest równocześnie prosta (na poziomie reguł konstrukcyjnych), jak i niepomiernie złożona (na poziomie otrzymanego obrazu/modelu rzeczywistości). Szczególnie ważnym dla mnie jest fakt, że gra w Go jest w Chinach i Japonii traktowana jako praktyka życiowa, medytacyjna, związana odpowiednio z filozofią konfucjańską (Moskowitz, 2013, s. 72 74) i koncepcją „Drogi” (Dao/Do). Uprawianie gry jest więc zarazem: grą, praktykowaniem pewnego modelu logiczno-filozoficznego, stylem życia i praktyką duchową. Takie wielopłaszczyznowe ujęcie można redukcyjnie opisać jako „wykonywanie” (enact) „gry w grę”. Pojawiające się powyżej motywy, odwołujące się do konceptu Drogi (Do) (Cynarski, 2000) oraz ideałów konfucjańskich, ujawniają ważny i złożony problem relacji pomiędzy ontologią i aksjologią, co dotyczy zarówno gry w Go/Weiqi, inspirowanych przez nią praktyk kulturowych, jak i teorii aktora-sieci (ANT).

W tym miejscu warto wprowadzić odniesienie do Andrew Feenberga - filozofa techniki, znawcy zarówno STS i ANT, jak i gry w Go/Weiqi ${ }^{7}$. Jest on dla mnie ważnym odniesieniem, gdyż główny motyw jego twórczości filozoficznej jest analogiczny do moich wysiłków, stara się on pogodzić wydajność ontologiczną ANT z aksjologicznym wymiarem krytyki (Nowak, 2015, 2016). Feenberg czyni to, próbując połączyć studia nad nauką i techniką z refleksją odwołującą się do Lukácsa, Marcusego i częściowo Heideggera. Nie będę przywoływał tej szerokiej gamy odniesień filozoficznych i skupię się na książce Feenberga, w której bezpośrednio nawiązuje on do filozoficznych aspektów modernizacji kultury

\footnotetext{
${ }^{7}$ W rozmowie z Andrew Feenbergiem zapytałem go, czy jest graczem w Go - stwierdził, że nie tylko gra, ale jest ona jego pasją (spędził ono wiele czasu w Japonii, co ułatwiało praktykę gry).
} 
japońskiej, w tym do odwołań do gry w Go. Szczególnie ważna dla mnie będzie dokonana przez niego analiza pojęcia Drogi (Do):

Ten charakterystyczny japoński koncept Drogi ma dwustopniową strukturę. Aktywność, która może zostać użyta w celu wsparcia Drogi, poddana zostaje metodycznej abstrakcji z przygodności codziennego życia i skonstruowana jako autonomiczne „pole” ze swoją własną logiką. Następnie pole to musi się stać miejscem refleksyjnego skupienia i samotransformacji dla aktora w ową aktywność zaangażowanego. (Feenberg, 1995, s. 197)

Dialektyczna zależność pomiędzy autonomizacją pola a pełnym zaangażowania byciem-w-aktywności jest kluczowa dla osiągnięcia mistrzostwa w działaniu. Jak wskazuje Flyvbjerg, który powołując się na badania Dreyfusów próbuje dokonać uwspółcześnienia pojęcia działania roztropnego (phronesis), taka kolista, dialektyczna struktura jest uniwersalnym modelem opisującym kognitywne procesy nabywania umiejętności i osiąganie poziomu mistrzowskiego w wybranym aspekcie działania (Dreyfus, S. E., Dreyfus, H. L., 1980; Flyvbjerg, 2001). Zrekonstruowanie autonomicznego pola, które tworzy sieć reguł wykonywania/grania - czy to w przypadku gry w Go/Weiqi, czy to w wypadku koncepcji ontologiczno-filozoficznej, jest pierwszym krokiem, kolejnym jest sama praktyka gry (oraz jej uczenie się i nauczanie innych). Czyli ważne jest, aby nie pozostawać na poziomie regul, lecz wykonywać i praktykować je. Dlatego porównanie traktatu filozoficznego Nieredukcje do gry w Go pokazuje autonomiczność pola w ramach „gry w ANT”, które podobnie jak gra w Go/Weiqi: „musi stać się dla aktora miejscem refleksyjnego skupienia i samotransformacji w ową aktywność zaangażowanego" (Feenberg, 1995, s. 197). Dobrze to współgra z mityczną opowieścią o początkach gry w Go:

Mój mistrz pokazał mi, że gra Go to jednocześnie okrutna wojna, wielka budowa i mądre handlowanie - powiedział Dan Zhu. - Chcąc grać lepiej musiałem wiele się nauczyć i, jak widziałeś, starałem się to zrobić dobrze. (Lubos, 2008)

Przemiana wymaga równoczesnego opanowania reguł gry, jej praktykowania i przemiany samego gracza. Autonomizacja w przypadku gry w Go/Weiqi, jak wskazuje Andrew Feenberg, wynika z poniższych zasad - ruchy są podejmowane według jasnych, jednoznacznych reguł, są one pozbawione jakiekolwiek kontekstu semantycznego, ich cel jest spleciony ściśle z immanentnymi regułami samej gry. Wynik gry, decyzja o zwycięstwie również wynika z jasnych zasad. Ruchy są ściśle wyróżnione, mają swe „miejsce” i „czas”. Autonomia gry, jej specyficzne odseparowanie od kontekstu i środowiska pozwala na doskonalenie jej odgrywania. Proces samorefleksji doskonalony $\mathrm{w}$ jej trakcie splata się z życiem gracza, dzięki czemu gra nie służy jedynie doskonaleniu samej rozgrywki, ale staje się również katalizatorem jego przemian. Autonomizacja i rekontekstualizacja gry prowadzą do tego, że gracz zaczyna działać w ramach jednego „nie-dualistycznego” sposobu działania, określanego przywołanym wcześniej terminem Drogi (Do): 
Rekontekstualizujące praktykowanie gry jako Drogi oddziałuje z paradoksalnym efektem na autonomię - wzmacniając ją. Gra w całości zostaje wchłonięta przez praktykę życiową, która z kolei zostaje w pełni wchłonięta przez grę. (Feenberg, 1995, s. 198)

Gra staje się drogą, powołaniem, praktyką samorealizacji. Ale pozostanie na poziomie autonomizacji nie wystarcza, konieczna jest rekontekstualizacja, zanurzenie w praktykach. Dopiero dzięki pracy przekładu pomiędzy wypracowaną w grze dyscypliną a byciem w środowisku osiągany jest efekt Drogi. Taka konieczność mediowania, przechodzenia pomiędzy autonomicznym wnętrzem a heteronomicznym środowiskiem została dobrze opisana przez Latoura, gdy przedstawiał on, w jaki sposób doszło do sukcesu Pasteura (Latour, 1988, 2009). Zwróćmy uwagę, że odwołujący się do Tołstoja opis owej zwycięskiej „wojny z mikrobami”, toczonej przez Pasteura stanowi pierwszą część tomu, w drugiej zawarty jest traktat Nieredukcje. Latour wskazywał, w jaki sposób z jednej strony musi zostać zachowana autonomia pola „laboratorium” z jego specyficznymi regułami, wypracowanymi procedurami a drugiej strony, że sukces możliwy jest tylko poprzez praktyki rekontekstualizacji nie tylko dlatego, że odkrycie laboratoryjne powinno być „stosowalne”, ale przede wszystkim dlatego, że całość procesu poznawczego wymaga nieustannego przechodzenia, translacji pomiędzy autonomicznym polem laboratorium a środowiskiem. Dzięki temu Pasteur może „spasteryzować” Francję, czyli z sukcesem wprowadzić innowację, jaką jest szczepionka. Pasteur nie mógł walczyć z mikrobami bezpośrednio, nie mógł im wydać wojny frontalnej, ale raczej w duchu Mao Zedonga (Mao, 2012 (1938)) czy w stylu gry w Go/Weiqi musiał dokonywać „przewlekłej wojny”, zarządzać warunki brzegowe, zajmować i tworzyć stabilne „masywy i wysepki”, dzięki którym mógł rozszerzać obszar swojego oddziaływania aż po zwycięstwo - otoczenie przeciwnika i ustabilizowanie sytuacji na „planszy” wedle swoich reguł. Uwidacznia się tu ważny aspekt ANT, związanie analizy mikro- i makropoziomowej (Callon, Latour, 1981). Pasteur osiąga sukces, gdyż podobnie jak Mao w swej wojnie partyzanckiej albo jak dobry gracz łączy w sobie zdolności strategiczne, taktyczne, jak i etos. Zasada „gry” przenika całość rzeczywistości i pozwala na zwycięstwo w świecie definiowanym przez proste nietzscheańsko-darwinowskie reguły - wygrywa ta wersja rzeczywistości, która się ustabilizowała i wyłoniła z morza nieskończonych alternatyw.

Praktykowanie gry jako drogi jest dla mnie kluczowe, gdyż pokazuje, że można uczyć się tego, w jaki sposób współtworzyć i stabilizować rzeczywistość, w jaki sposób poprzez „przewlekłą wojnę”, działania niebezpośrednie można wpływać na to, aby pożądany przez nas aksjologicznie stan rzeczywistości się ustabilizował i trwał. Z jednej strony działanie powinno być oparte o sferę autonomiczną, z jej własnymi regułami, z drugiej powinien zachodzić analogiczny jak w przypadku gry w Go/Weiqi, czy w przypadku odkrycia szczepionki przez Pasteura, proces jego translacji. 
Wracając do gry w Go/Weiqi - opisane powyżej reguły brzmieć mogą nazbyt metaforycznie, kluczowe jest zrozumienie wagi praktyki, wykonywania pełnego zaangażowania zanurzonego uczestnictwa, które jest jednocześnie warunkowane momentem autonomizacji. To moment jedności gry i jej wykonywania, który Bourdieu oddawał terminem illusio. Opisywanie praktyk gry nie oddaje tego, co może być dobrze uchwycone podczas gry w Go/Weiqi. Piszący te słowa jest $\mathrm{w}$ tej komfortowej sytuacji, że bywał graczem w Go/Weiqi, w pewnym okresie nawet uczęszczałem do klubu i brałem udział w zawodach, a ukoronowaniem krótkiej kariery amatorskiej było uczestnictwo w turnieju z okazji Dni Japonii pod patronatem ambasady tego kraju. Do dziś pamiętam, że na tym turnieju grałem z mistrzem na poziomie kilku Dan (w Go/Weiqi dzięki rozbudowanemu systemowi handicapów pojedynek taki nie jest wcale pozbawiony sensu). Mistrz nie ograniczał się jedynie do gry, ale także komentował ją, ucząc mnie i innych oglądających grę pewnego specyficznego sposobu myślenia o niej. W Go/Weiqi, jak już wspomniałem wyżej ze względu na złożoność i ilość potencjalnych kombinacji, nie jest możliwe zapamiętywanie ruchów, przewidywanie ich, planowanie. Kluczowe jest natomiast uczenie się pewnej sytuacyjnej mądrości, która w każdej grze pozwala rozpoznawać nie konkretne „ruchy” czy formacje kamieni, ponieważ te zmieniają się zbyt często w ramach różnych partii, ale by sytuacyjnie rozumieć rodzącą się dynamikę gry, wyrabiając wrażliwość na sekwencję, wydarzanie się „sytuacji”. Gra w Go/Weiqi uczy rozpoznawania wzorców, myślenia w stylu Gestalt. Mistrz gry podczas swych komentarzy nieustannie odwoływał się do metafory wpływów, siły i napięcia, a także oporu (zauważmy, jak dobrze współgrają one ze słownikiem ANT). W grze kluczowe było budowanie układów, które będą na tyle silne, że przetrwają, kiedy gracz będzie zmuszony do obrony pozycji w innej części planszy. Partia gry była skomplikowanym teatrem sił, powstawania momentów stabilizacji i destabilizacji, zawiązywaniem się sojuszy pionów, które tworzyły strukturę i ich rozpadem. Wykładając pojedynczy pion/kamień na planszy, mistrz równocześnie komentował, w jaki sposób ów kamień gra z układem sił na niej, w jaki sposób go zakłóca. Kolejny ruch gracza musiał mierzyć się ze zmienionym układem sił, negocjować już z innymi siłami, wpływając zarazem na kolejne, nowe układy sił. Pomimo że dla laika mogło to wyglądać jak pseudomistyczne uwagi w stylu „new age”, dla osoby grającej, a szczególnie dla mnie, który nie tylko znał reguły gry, ale właśnie w tę partię był zaangażowany, było to całkowicie zrozumiałe. Niestety nie osiągnąłem takiego poziomu gry, nie zinternalizowałem na tyle reguł, żeby móc taką swobodę, taką zdolność „czytania” planszy osiągnąć samemu.

Praktykowanie gry, uczestniczenie w owej podwojonej grze autonomizacji i kontekstualizacji pozwala na ten rodzaj refleksyjności, który wymyka się przeracjonalizowanym, „,efalocentrycznym” analizom (znów pozwalając sobie na metaforę zaczerpniętą od Bourdieu). Gra w Go/Weiqi pozwala na uczestnictwo w tym, co znów górnolotnie Heidegger nazywał „wydarzaniem”. 
Przyjrzyjmy się „gęstym”, reporterskim opisom gry w Go sporządzonym przez Kawabatę, pozwoli to choć $\mathrm{w}$ minimalnym stopniu przybliżyć atmosferę i specyfikę gry także tym czytelniczkom i czytelnikom, którzy nie mieli możliwości grania w nią:

Mistrz budował tę partię jak dzieło sztuki. I nagle, w momencie gdy w najwyższym skupieniu nad nim pracuje, ktoś - by przyrównać to dzieło do obrazu - oblewa je czarną farbą. W go, w zmaganiach Czarnych z Białymi, jest miejsce na zamysł twórczy i na jego kształt formalny i - jak w muzyce - są w nim i wzloty ducha, i linia melodyczna. Kiedy nagle zakradnie się dysonans albo gdy partner zakłóci znienacka wykonanie, wszystko może lec w gruzach. [...] Nie da się zaprzeczyć, że ruchem Czarnych 121 Otake wprawił wszystkich w osłupienie, wzbudził nasze podejrzenia i wątpliwości, a tym samym zakłócił jej rytm. (Kawabata, 2004, s. 150)

W powyższym cytacie (tendencyjnie waloryzującym Mistrza) widać wyraźnie, że gra w Go/Weiqi była sposobem komunikacji, ale rozumianej nie jako dualizujący język, lecz jako przeobrażająca graczy praktyka życiowa. Feenberg wskazuje, że koncept Drogi (Do) bazuje na koncepcji „pustego umysłu”, sposobu działania opartego o niedualizujący sposób działania i mówienia, specyficznie rozumianą praxis.

Prawdziwa nie-dualność [nonduality] nie może być osiągnięta poprzez obserwację konfliktów, w które inni są uwikłani, niezależnie jak dialektyczni będziemy. Obserwator wciąż będzie tkwił w dualistycznej opozycji względem obiektu. Pusty umysł [no-mind] jest raczej swoistą drogą życia w dualizmie, egzystencjalnym usytuowaniem bycia w jego wnętrzu, a nie modalnością wiedzy polegającą na przekraczaniu go. (Feenberg, 1995, s. 199)

Ta próba wyrażenia napięcia pomiędzy dualizmem pojawiającym się z konieczności na poziomie języka czy w ramach struktur wiedzy a unifikującą rolą praktyki jest widoczna także $\mathrm{w}$ ramach teorii aktora-sieci. Abriszewski porównuje teorię aktora-sieci z nie-dualizującym sposobem filozofowania zaproponowanym przez Miterera (Arbiszewski, 2010). Nie będę teraz odtwarzał dokonanych przez Abriszewskiego analiz, dla naszych potrzeb wystarczy wskazać, że przywoływana wcześniej praktyka translacji, tak kluczowa w ramach teorii aktora-sieci, jest zrozumiała w pełni dopiero wtedy, gdy potraktujemy ją analogicznie jak wyżej opisaną praktykę gry w Go/Weiqi czy praktykowanie Drogi $(D o)$. Dualizujące opisy nie będą całkowicie zrozumiałe poza kontekstem praktykowania/wykonywania. ANT nie jest teorią, którą wystarczy odtworzyć i zrekonstruować. To raczej zbiór reguł gry, praktyk, które nabierają sensu, gdy działamy (gramy). Jednoczący moment praktyki jest jedynym sposobem na wyjście z paradoksów, w które uwikłamy się, gdy ANT traktowane będzie jedynie jako opis. 


\section{Grając w zmienianie świata}

Praktykowanie gry w Go/Weiqi, podobnie jak analizy w duchu teorii aktorasieci, uczy pewnego nastawienia, dyspozycji, którą można zastosować jako narzędzie analizy i zmieniania świata:

Sytuacja jest bardziej zagmatwana, ponieważ jak wielu antropologów pokazało, ludzie przyjmują „lokalizm” nawet szybciej niż globalizacja, która podobno miała go zniszczyć. Tradycje są wynajdywane każdego dnia, pojawiają się całe nowe kultury, wynajdywane są języki, podobnie jak przynależności religijne, są one (lokalizmy) może nawet bardziej okopane [entrenched] niż wcześniej. Jeżeli przyjąć, że metafora „korzeni” została odwrócona „do góry nogami”, to dzięki siłom modernizacji nawet najbardziej oddalone od siebie tożsamości łączyły się ze sobą. Modernizacja, tak jasna na swych liniach frontu, stała się zagmatwana jak gra w go w połowie rozgrywki. (Latour, 2005)

Widzimy znów odwołanie do gry w Go/Weiqi i to przy użyciu metaforyki wojennej: linie frontu (frontlines), okopanie się (entreched). Działanie społeczne, polityczne jest zatem nietzscheańską grą wojenną, opisywalną dobrze zarówno przez „aparaturę teoretyczną” teorii aktora-sieci, jak i przez metaforykę zaczerpniętą z Go/Weiqi.

Gra w Go/Weiqi może zatem stanowić trening wyrabiania pewnej dyspozycji, uczenia pewnego sposobu myślenia i działania, który pozwala także praktykować tę postawę filozoficzną poza grą. W pewnym sensie gra w Go/Weiqi uczy podstawowych reguł, jak zostać „antografem”, czyli badaczem ANT (w wersji uogólnionej możemy takiego badacza nazwać „ontografem” (Lynch, 2013), czyli badaczem ontologii). Metaforę „,antografa” zawdzięczam błyskotliwej uwadze Marcina Zaroda. Metafora ta, przywołując skojarzenie z pantografem, dobrze współgra z metaforą torów kolejowych, które służą Latourowi do opisania, w jaki sposób „krążą” fakty naukowe.

To dość zabawne, ile śliny (łącznie $\mathrm{z}$ moją) zostało wytoczone $\mathrm{w}$ walce $\mathrm{z}$ „korespondencyjną teorią prawdy", którą tak zwolennicy, jak i przeciwnicy rozumieli jako skok [leap] pomiędzy obiektem a podmiotem, bez prób dociekania bliżej natury samego połączenia [correspondence]. Pociągi i metro oferują lepszą metaforę korespondencji: nie zmieniasz jednej linii metra na inną, o ile nie istnieje ciąg peronów i tuneli pozwalających ci na połączenie [correspond] zgodnie z rozkładem jazdy. [...] Jeżeli akceptujesz tę nową metaforykę, to postępem jest, kiedy zastępujesz pojedynczą, izolowaną, źle zaopatrzoną i remontowaną prostą linię kolejową do złożonej sieci dobrze utrzymanych stacji, pozwalających na ustanowienie wielu połączeń [correspondences]. Stąd „naprzód” [forward] oznacza przejście od złej do dobrej sieci. Każdy mieszkaniec dużego miasta z dobrym lub złym transportem publicznym zrozumie łatwo tę różnicę. (Latour, 2007, s. 96)

Antograf zatem to ktoś, kto jest w stanie łączyć pasażerów-użytkowników wiedzy oraz „tory” - sieci warunkujące istnienie wiedzy z krążącymi po nich pociągami - z faktami, uwzględniając wymogi systemowe („rozkład jazdy”). Antograf, przywołując metaforykę gry w Go/ANT, byłby zatem zdolnym „czytać 
planszę", widzieć rozgrywkę holistycznie, występujące na planszy (goban) napięcia, przepływy, potrafiłby dostrzec połączenia pomiędzy pozornie odległymi obszarami planszy. Co więcej umiałby on „przełączać uwagę” pomiędzy różnymi obszarami gry, skupiając się na tych, które wymagają interwencji, a porzucając te, których „wyistaczanie”, samoorganizacja nie zagraża całości rozgrywki. W tym sensie Latour ma rację, gdy przywołuje metaforę gry w Go w kontekście modernizacji, gdyż dyspozycja uzyskiwania w ramach jej praktykowania uczy dyspozycji filozoficznej, pozwalającej „odmyśleć” nowoczesny, kantowskiej proweniencji podział na fakty i wartości, zdeterminowany świat przedmiotowy i podmiotowo-duchowy świat wolności. Latour, odwołując się do gry w Go/Weiqi, jej reguł i praktykowania, zawiązał specyficzny, bardzo hermetyczny sojusz z tymi nielicznymi czytelnikami, którzy w ową grę grali. Można zarzucić Latourowi oraz autorowi niniejszego tekstu, że powiązanie filozoficznej i ontologicznej „zawartości ANT” z grą w Go/Weiqi jest rodzajem próżnego gestu, epatowaniem egzotyką czy pseudoerudycją. Owszem, można zauważyć, że wśród czytelników prac z zakresu teorii aktora-sieci nie ma wielu graczy w Go/Weiqi, ale podobnie ograniczona grupa czytelników kiedykolwiek uczestniczyła w badaniach naukowych, a jeszcze mniejsza została etnografami nauki. Przypuszczam, że amatorskie opanowanie gry w Go/Weiqi wymaga jednak mniejszego nakładu środków i mniejszych opłat „na wejściu” niż zapoznanie się z funkcjonowaniem laboratoriów naukowych. W ten sposób, jak gdyby „tylnymi drzwiami”, mamy szansę posiąść pewną ważną dyspozycję filozoficzną. Odwołanie do ,gry w Go/Weiqi” rozumiem jako grę z czytelnikiem: „nie rozumiesz odwołania do tej gry w moim tekście - spróbuj sam zagrać, to zrozumiesz”. Dokładnie tak pojmuję również sens czytania prac z zakresu teorii aktora-sieci: jako zachęty do „gry w grę”, dopiero bowiem praktykowanie/wykonywanie czyni ANT zrozumiałą.

Powyższe wezwanie do „grania w grę” uczy nas jeszcze jednego, ukazuje w jakiś sposób, że myślenie i działanie ucieleśniane przez grę może stać się „generatorem ontologicznym”. Poprzez „generator ontologiczny” rozumiem czynnik (teorię, tekst, zjawisko społeczne), które splata, składa wiele bytów, sieci ze sobą, wpływa i zmienia stan rzeczywistości (Callon, 2009). Takim generatorem może też być teoria, tekst naukowy, popularny wykład wygłaszany przez naukowego celebrytę. Praktykowanie ANT, jak już wskazałem wyżej, to nie tylko zatrzymanie się na poziomie opisu, teorii, ale także analiza ontologiczna tego, jak moje usytuowanie wpływa na zmianę mikrokosmosu (a także mezo- i makrokosmosu). Analogicznie gra w Go/Weiqi może zostać potraktowana jako coś więcej niż jej immanentność, ograniczenie do pola autonomii. Kontekstualizacja wspomniana wyżej nie musi ograniczać się jedynie do przemiany duchowej, samorefleksji gracza - może być potraktowana dużo 
szerzej. W przywoływanej powieści partia w Go/Weiqi pomiędzy starym mistrzem - Mejinem ${ }^{8}$ a pretendentem do tego miana Onodą ${ }^{9}$ jest dobrym przykładem takiego generatora ontologicznego. Partia ta trwała od 26 czerwca do 4 grudnia 1938 roku i stała się wydarzeniem, które nie tylko kształtowało życie graczy, ale także było szeroko komentowane, skupiało uwagę całej Japonii. Ze względu na chorobę mistrza partię tę rozgrywano $\mathrm{z}$ dużymi przerwami czasowymi, opisywano ją w gazetach (powieść Kawabaty stanowi fabularyzowaną wersję jego własnych sprawozdań z tej partii, drukowanych w odcinkach $\mathrm{w}$ jednej $\mathrm{z}$ gazet). W książce widać wyraźnie, że „partia gry w Go/Weiqi” niczego nie przedstawia ani nie ilustruje (byłoby to wręcz niemożliwe zważywszy na jej abstrakcyjny charakter), ale jest ona w stanie przeobrażać rzeczywistość. Podobnie jak w samej grze piony, wchodząc w relacje, tworzą rzeczywistość o określonych cechach, tak sama partia gry, wchodząc $\mathrm{w}$ relacje $\mathrm{z}$ grającymi, widzami, kibicami na odległość kształtuje rzeczywistość Japonii w 1938 roku. W powieści tej uwidacznia się ważna dla ANT obserwacja, że możliwe jest opisanie przejść od tego, w jaki sposób mikroaktorzy stają się makro-aktorami. Książka Kawabaty jest cenna na kilku poziomach - jest ciekawym opisem gry, która sama może być modelem systemu filozoficznego Latoura, ukazuje „metafizykę empiryczną” w działaniu oraz pokazuje, w jaki sposób można dokonać translacji pomiędzy grą w Go/Weiqi („modelem ANT”) a przeobrażaniem się społeczeństwa poprzez oddziaływanie owego modelu metafizycznego symbolizowanego przez grę. Nie dzieje się tak jednak dlatego, że myśl „niezapośredniczona” oddziałuje na rzeczywistość, ale dlatego, że można pokazać w ramach jednej relacyjnej ontologii, w jaki sposób zachodzi translacja, przejście pomiędzy położeniem na przecięciu kamienia określonego koloru a uruchomieniem całego szeregu przekształceń zbiorowości, jaką była Japonia w 1938 roku. Warto dodać, wskazując na powyżej przywołaną wypowiedź Latoura, że opisana w powieści partia pomiędzy mistrzem a pretendentem do tego miana stała się wypowiedzią w toczącym się w Japonii sporze na temat modernizacji kraju, obrony tradycji, sposobów przeprowadzania (lub zaniechania) reform.

Można powiedzieć, że w ostatniej partii swego życia Mistrz ucierpiał z powodu typowego dla nowych czasów racjonalizmu, który podporządkowując wszystko pedantycznym przepisom, sprawił, że ulotniły się gdzieś urok i wykwintność Sztuki, że zabrakło miejsca na respekt dla starszych, na wzajemny szacunek. (Kawabata, 2004, s. 44)

Gra w Go/Weiqi staje się też matrycą, która autorowi pozwala nie tylko na przedstawienie dyskusji o modernizacji Japonii, lecz służy również do wypowiedzi na temat różnic kulturowych. Autor zauważa, że w krajach

\footnotetext{
${ }^{8}$ Postać Mistrza była wzorowane na postaci Honinbo Shusai.

${ }^{9}$ Prawdziwe nazwisko to Kitani Minoru.
} 
zachodu Go/Weiqi jest traktowane jedynie jako gra w oderwaniu od całościowego nastawienia Japończyków, traktujących ją jako sztukę życia (Kawabata, 2004, s. 106).

Nie jestem jedynym, którzy w grze w Go/Weiqi poszukuje wzoru, modelu tak pewnego stylu filozofowania, jak klucza do kultury Japonii. Jak wskazywałem wyżej, opisana w powieści Kawabaty partia Go/Weiqi stała się w Japonii ważnym punktem odniesienia dyskusji na temat dróg modernizacji tego kraju. Przywoływany już przeze mnie Andrew Feenberg w książce Alternative Modernity używa odwołania do gry w Go/Weiqi w aż trzech aspektach: przedstawia grę w Go/Weiqi jako pewną propozycję metafizyczną, odtwarza dyskusje wokół modernizacji Japonii oraz proponuje ścieżkę tak zwanej modernizacji alternatywnej. Partia Mistrza z Otake staje się dla Feenberga symbolicznym pojedynkiem pomiędzy starą, tradycyjną Japonią a jej nowym zmodernizowanym obliczem (Feenberg, 1995, s. 204). Wskazuje on, że opis partii przekazany nam przez Kawabatę jest wypowiedzią na temat dróg modernizacji Japonii, zbliżoną do diagnozy zawartej w dialektycznej koncepcji Nishidy. Filozof ten starał się pogodzić skuteczność instrumentalnej racjonalności ucieleśnionej przez zachodnią technonaukę z japońskim zapleczem kulturowym, które starało się tworzyć spójny, harmonijny organizm. Odwołanie do powieści Kawabaty oraz zwrócenie uwagi na grę w Go/Weiqi jako swoisty „system racjonalny” pozwala mu pokazać w sposób metaforyczny możliwość zaistnienia relatywnie autonomicznej, nie-zachodniej nowoczesności w Japonii (Feenberg, 1995, s. 215).

Alternatywne ścieżki modernizacji, które w dużej mierze określały transformację Japonii, związane były, jak wskazuje Feenberg, między innymi ze specyficzną kategorią „miejsca”: „Jest to doświadczenie poszukiwania właściwego «miejsca» $w$ systemie społecznych relacji, które każdy musi samodzielnie znaleźć" (Feenberg, 1995, s. 216). Feenberg przestrzega przed pośpieszną interpretacją, która pojęcie miejsca wiąże z tradycjonalizmem i je ideologizuje. Wskazuje on raczej na to, że należy owo „miejsce” rozumieć jako usytuowanie, swoistą syntezę racjonalności, która równocześnie nie operuje w pustym świecie bez właściwości. „Miejsce”, usytuowanie oznacza raczej pełną świadomość zanurzenia w relatywnym świecie gry (gier) i świadomość, że każdorazowo racjonalność musi być równocześnie grą pomiędzy sferą autonomii (formalnych reguł) i ich wykonywaniem.

\section{Gra i ontologia wyboru}

Gra w Go/Weiqi, podobnie jak teoria aktora-sieci, są dla mnie ważne, gdyż związują ze sobą procesualną, relatywistyczną ontologię z aksjologią. W obu ujęciach: propozycji onto-metodologicznej ANT, jak w praktyce gry w Go/Weiqi 
uwidacznia się ontologiczny „ciężar wyboru”10. Każde położenie kamienia na planszy wpływa na rekonfigurację przyszłych stanów gry, ale także dokonuje rekonfiguracji stanów przeszłych. Każdy ruch, choć skrajnie usytuowany, jest równocześnie spleciony z całością gry, a nawet - jak pokazała to opowieść Kawabaty $-\mathrm{z}$ dyskusją o losach całego narodu. Połączona analiza gry w Go/Weiqi oraz ANT pozwala moim zdaniem zapoznać się z ważną dyspozycją praktyczno-teoretyczną, którą nazywam wyobraźnią ontologiczną (Nowak, 2013, 2015). Jednym z kluczowym aspektów tej dyspozycji jest zerwanie z założeniem charakterystycznym dla tak zwanej filozofii dostępu (Harman, 2016), głoszącym, że ontologia jest czymś zewnętrznym w stosunku do naszej praktyki życiowej i wynikających z niej nierozerwalnie kwestii aksjologicznych. Porzucenie założenia o zewnętrzności ontologii i myślenie w perspektywie wyobraźni ontologicznej to zdolność pomyślenia o grze w Go/Weiqi zarówno z perspektywy gracza, reguł gry (jej autonomii), jak i wagi pojedynczego kamienia. To dzięki tak wykształconej perspektywie uzyskujemy poczucie wagi wyboru ontologicznego. Z perspektywy gry w Go/Weiqi musimy porzucić założenie o „pojedynczości świata” (Law, 2015) i uznać ontologicznie rozumiany pluralizm. Widoczne jest to dobrze w praktyce gry, nie ma przepisu na jedną właściwie rozegraną partię gry w Go/Weiqi. Ale równocześnie istnieje tylko jedna faktyczna wersja tej gry, którą właśnie ukończyliśmy. Dobrze to koresponduje $\mathrm{z}$ rozstrzygnięciami dokonanymi w obrębie zwrotu ontologicznego (Heur van i in., 2013) - zamiast epistemologicznego perspektywizmu mamy do czynienia z kosmopolitycznym wyborem. Kosmopolityzm to zdolność do postrzegania i działania w obliczu złożoności świata (cosmos), wymagająca specyficznej dyspozycji - „ekologii działań [ecology of practices]” (Latour, 2004; Stengers, 2010, VII).

Ontologicznie warunkowany kosmopolityczny wybór to konieczność obrania konkretnej drogi z pełną świadomością, że z każdym wyborem otwieramy możliwość „wykonywania” (enact) pewnego świata, a zamykamy i uniemożliwiamy ustanawianie innego. Wybór ten staje się „ciężki” od odpowiedzialności jak ciężar kamienia kładzionego na gobanie (planszy) w trakcie rozgrywki ścieżki raz obrane determinują dalsze wybory. Nieprzypadkowo większość czasu rozgrywki w Go/Weiqi zajmuje początkowa faza gry (joseki).

Ekologia działań, ontonormy, kosmopolityka to różne określenia na ważną konsekwencję zwrotu (zwrotów) ontologicznego we współczesnych naukach społecznych (szczególnie STS/ANT). Ontologie proponowane przez omawianych wyżej badaczy i badaczki, ale i doświadczonych graczy w Go/Weiqi, to propozycja świata, który jest „pluriwersum”, jest dynamicznym światem „przemagających się”, samoorganizujących porządków. Dynamiczne ontologie przywracają $\mathrm{w}$ pewnym sensie nieodczarowany świat do tego stopnia, że

${ }^{10}$ Koresponduje to z jakościowym i ontologicznym rozumieniem „ciężkości” i powolności (por. Deleuze, Guattari, 2015, s. 457). 
można zaryzykować stwierdzenie, iż mamy tu do czynienia z powrotem do jakiejś formy hylozoimu, tak widocznej podczas rozgrywki w Go/Weiqi z jej metaforami wpływów, oddziaływań, sił. Ontologia proponowana przez ANT oraz Go/Weiqi uczy nas, że wybór nie jest tylko epistemologiczną operacją poznawczą, ale z konieczności również uwikłanym, usytuowanym uczestnictwem w zmienianiu zbiorowości.

\section{Bibliografia}

Abriszewski, K. (2008). Poznanie, zbiorowość, polityka: Analiza teorii aktora-sieci Bruno Latoura. Towarzystwo Autorów i Wydawców Prac Naukowych" Universitas".

Abriszewski, K. (2016). My jako podmioty społecznie konstruowanej wiedzy. Reinterpretacje i uzupełnienia fenomenologii społecznej Petera Bergera i Thomasa Luckmanna. Filozofia i Nauka. (4), 191-215.

Arbiszewski, K. (2010). Wszystko otwarte na nowo, Teoria Aktora-Sieci i filozofia kultury. Toru, Wydawnictwo Naukowe Uniwersytetu Mikołaja Kopernika.

Bińczyk, E., Derra, A., Grygieńć, J. (2015). Horyzont Konstruktywizmu. Inspiracje, perspektywy, przyszłość. Toruń: Wydawnictwo Naukowe UMK.

Boorman, S. A. (1969). The protracted game: A wei-ch $i$ interpretation of Maoist revolutionary strategy. Oxford University Press.

Callon, M. (2009). Acting in an uncertain world. MIT press.

Callon, M., Latour, B. (1981). Unscrewing the big Leviathan: How actors macro-structure reality and how sociologists help them to do so. Advances in social theory and methodology: Toward an integration of micro-and macro-sociologies, 1.

Cynarski, W. J. (2000). Ontologia i aksjologia. IDO Ruch dla Kultury, 1, 54.

Deleuze, G., Guattari, F. (1988). Traktat o nomadologii: Maszyna wojenna, przeł. Colloquia Communia, 36 (1-3)(1-3), 239-252.

Deleuze, G. (1993). Nietzsche i filozofia, tłum. B. Banasiak, Warszawa (wiele wydań).

Deleuze, G., Guattari, F. (2015). Tysiąc plateau, przeł. Warszawa: J. Bednarek, B ę c Zmiana,

Dreyfus, S. E., Dreyfus, H. L. (1980). A five-stage model of the mental activities involved in directed skill acquisition.

Feenberg, A. (1995). Alternative Modernity: The Technical Turn in Philosophy and Social Theory. Univ of California Press.

Flyvbjerg, B. (2001). Making social science matter: Why social inquiry fails and how it can succeed again. Cambridge university press.

Hämäläinen, N., Lehtonen, T.-K. (2016). Latour's empirical metaphysics. Distinktion: Journal of Social Theory, 17(1), 20-37.

Harman, G. (2016). Książę Sieci-Bruno Latour i Metafizyka. 
Heidegger, M. (2001). Wyzwolenie, tłum. J. Mizera. Kraków: Wydawnictwo Baran i Suszczyński.

Heur van, B., Leydesdorff, L., Wyatt, S. (2013). Turning to ontology in STS? Turning to STS through 'ontology'. Social Studies of Science, 43(3), 341-362.

James, W. (1958). Doświadczenia religijne. Książka i Wiedza.

Kawabata, Y. (2004). Meijin - mistrz go. Warszawa - Bielsko-Biała: Wydawnictwo ELAY.

Kazibut, R. (2013). „Wojny o naukę"-geneza, strony konfliktu i problemy do rozwiązania.

Knorr-Cetina, K. (1985). Germ warfare. Social Studies of Science, 15(3), 577-586.

Kostyszak, M. (2010). Krytyka ontoteologii w pismach Nietzschego, Heideggera i Derridy. Oficyna Wydawnicza Arboretum, Wrocław.

Krarup, T. M., Blok, A. (2011). Unfolding the social: quasi-actants, virtual theory, and the new empiricism of Bruno Latour. The Sociological Review, 59(1), 42-63.

Kraszek, J. (2008). Swiat Go. Wydawnictwo Olesiejuk.

Kuszyk-Bytniewska, M. (2015). Działanie wobec rzeczywistości: projekt onto-epistemologii spolecznej. Wydawnictwo Uniwersytetu Marii Curie-Skłodowskiej.

Lai, D. (2004). Learning from the stones: A Go approach to Mastering China's strategic concept, Shi. Pobrane $\mathrm{z}$ strony internetowej od Strategic Studies Institute, http://ssi.armywarcollege.edu/pdffiles/PUB378.pdf

Latour, B. (1988). The Pasteurization of France. Cambridge Mass: Harvard University Press.

Latour, B. (2004). Whose cosmos, which cosmopolitics? Comments on the peace terms of Ulrich Beck. Common Knowledge, 10(3), 450-462.

Latour, B. (2005). On the Difficulty of Being Glocal. Art-e-fact: Strategies of Resistance, 4.

Latour, B. (2007). A Textbook Case Revisited. Knowledge as mode of existence. W: E. J. Hackett \& O. Amsterdamska (red.), The Handbook of Science and Technology Studies, third edition. Cambridge, MA, USA: MIT press.

Latour, B. (2008). What is the style of matters of concern?: two lectures in empirical Philosophy. Koninklijke Van Gorcum Assen.

Latour, B. (2009). Dajcie mi laboratorium a poruszę świat. Teksty drugie. (1-2), 163-192.

Latour, B. (2012). Wizualizacja i poznanie: Zrysowywanie rzeczy razem. Przeł. A. Derra, M. Frackowski. Avant, 3, 207-257.

Latour, B. (2013). An inquiry into modes of existence. Harvard University Press.

Latour, B., Woolgar, S. (1986). Laboratory Life: The Construction of Scientific Knowledge. Princeton: Princeton University Press.

Law, J. (2004). After Method: Mess in Social Science Research. London-New York: Routledge-Taylor \& Francis Group. 
Law, J. (2015). What's wrong with a one-world world? Distinktion: Scandinavian Journal of Social Theory, 16(1), 126-139.

Law, J., Lien, M. E. (2013). Slippery: Field notes in empirical ontology. Social Studies of Science, 43(3), 363-378. DOI: https://doi.org/10.1177/0306312712456947.

Lubos, J. J. (2008). Bajka o początkach Go. Pobrane z: http://poznan.go.art.pl/artykuly/bajka-o-poczatkach-go.

Lynch, M. (2013). Ontography: Investigating the production of things, deflating ontology. Social Studies of Science, 43(3), 444-462.

Maddalena, S. K. M. (2014). Mediating Atomistic Ontologies: LEGO, Synthetic Biology, and a Digital Episteme. Graduate Faculty of North Carolina State University.

Mao, T.-T. (Z.). (2012 (1938)). O przewlektej wojnie. Maoistowski Projekt Dokumentacyjny. Pobrane z: https://maopd.files.wordpress.com/2012/02/o-przewleklej-wojnie1938.pdf.

Moskowitz, M. L. (2013). Go nation: Chinese masculinities and the game of weiqi in China (nr. 28). Univ of California Press.

Mumford, S. (2013). The Metaphysics of Chess. Pobrane z: https://blogs.nottingham.ac.uk/artsmatters/2013/10/06/the-metaphysics-of-chess/.

Nowak, A. W. (2013). Wyobraźnia ontologiczna-przekraczanie metodologicznego solipsyzmu a obietnica badań interdyscyplinarnych. AVANT. Pismo Awangardy Filozoficzno-Naukowej. (2), 338-362. Pobrane z: http://avant.edu.pl/wp-content/uploads/Andrzej-W-Nowak-Wyobraznia-ontologiczna.pdf.

Nowak, A. W. (2015). Ontologia a aksjologia—co możemy zyskać, a co stracić, używając teorii aktora-sieci? Diagnoza wstępna. Prace Kulturoznawcze, 18, 65-79.

Nowak, A. W. (2016). Wyobraźnia ontologiczna. Poznań -Warszawa: Instytut Badań Literackich PAN, Wydawnictwo; Wydawnictwo Naukowe UAM.

Schmidgen, H. (2015). Bruno Latour in Pieces: An Intellectual Biography. New York: Fordham University Press.

Skórzyńska, A. (2017). Praxis i miasto: Ćwiczenia z kulturowych badań angażujących. NH. Nowa Humanistyka: t. 43. Warszawa: Instytut Badań Literackich PAN. Wydawnictwo.

Star, S. L. (1999). The Ethnography of Infrastructure. American Behavioral Scientist, 43(3), 377-391. DOI: https://doi.org/10.1177/00027649921955326.

Stengers, I. (2010). Cosmopolitics. Posthumanities: 9-10. Minneapolis: University of Minnesota Press.

Thoburn, N. (2008). What is a Militant? W: Deleuze and Politics (s. 98-120). Edinburgh University Press.

Thoburn, N. (2013). The Strangest Cult: Material Forms of the Political Book through Deleuze and Guattari. Deleuze Studies, 7(1), 53-82. DOI: https://doi.org/10.3366/dls.2013.0094.

Tuan, Y.-F. (1987). Przestrzeń i miejsce. Państwowy Instytut Wydawniczy. 
Tuchańska, B. (2006). O Sokalu z Bricmontem, Latourze io tym, co z tego (nie) wynika. Nauka, 1, 93-111.

Wasik, W., Cynarski, W. J. (2005). Związki go ze sztuką wojenną i dalekowschodnimi sztukami walki. Idō - Ruch dla Kultury : rocznik naukowy : [filozofia, nauka, tradycje wschodu, kultura, zdrowie, edukacja]. (5), 118-126.

Woolgar, S., Pawluch, D. (1985). Ontological Gerrymandering: The Anatomy of Social Problems Explanations. Social Problems, 32(3), 214-227. DOI: https://doi.org/10.2307/800680.

\title{
The burden of choice, the complexity of the world and its reduction: the game of Go/Weiqi as a practice of "empirical metaphysics"
}

\begin{abstract}
The main aim of the text is to show how a game of Go (Weiqi, baduk, Igo) can serve as a model representation of the ontological-metaphysical aspect of the actor-network theory (ANT). An additional objective is to demonstrate in return that this ontological-metaphysical aspect of ANT represented on Go/Weiqi game model is able to highlight the key aspect of this theory - onto-methodological praxis.
\end{abstract}

Keywords: games; Go/Weiqi; empirical metaphysics; ontological imagination; the actornetwork theory (ANT); studies on science and technology (STS) 